\title{
Ciência e Consciência
}

\author{
Science and Conscience
}

Harley E. A. Bicas

Não mais que no exíguo tempo de uma geração, antes que um moço ficasse velho, e tornando-se, sobretudo, bem difícil de assimilação pela intensidade da mudança, tudo ficou diferente. ("Tudo" parece liberdade retórica, que uma pessoa acostumada ao rigor analítico do método científico deveria rejeitar. Mas se novos costumes e até valores, relacionamentos e convicções foram suscitados, exigindo adaptações, é mesmo um estilo de vida completamente diferente que daí emerge.)

Entre os que podem se beneficiar das aquisições materiais do processo científico e tecnológico, hoje se vive mais e melhor, a comunicação nunca foi tão fácil, as distâncias se encurtaram, os acessos à informação e ao lazer são privilegiados. Enquanto também se discute sobre se os efeitos dessa febril produção trazem benefícios essenciais à humanidade, ou se eles são meramente ilusórios e circunstanciais, chegando até a desviá-la do exame de suas questões substantivas, o fato é que há também o lado negativo dessa modernização: extinção de ocupações, competições exacerbadas levando a deslealdades, desequilíbrios afetivos, massificação de opiniões e emoções; e daí por diante, sem falar daqueles que, excluidos de todo o sistema, vivem à sua margem. Subsiste, enfim, um estado de incerteza sobre como o homem absorve as transformações que ele mesmo produz, principalmente em face da vertiginosa velocidade com que elas ocorrem.

Mas é pouco provável que prevaleçam os argumentos acauteladores desse direcionamento de nossos desempenhos: a incessante busca de conhecimentos identifica-se como intrínseca à natureza humana e apenas se exacerba pela própria facilitação das interações pessoais (ultimamente elas também aceleradas, partes que são de um processo vicioso de auto-alimentação). Assim, ao equilíbrio do homem parecem necessárias tanto a sabedoria na condução de seu pensamento criador quanto a moderação na prática que dele se faz.

Tudo mudou. No campo profissional e simplesmente dentro de um curto período de vida, a Oftalmologia diversificouse em uma multiplicidade de sub (ou super) especializações, propondo e exigindo maior quantidade e qualidade de conhecimentos, a ponto de já se tornar humanamente inviável domi-

Professor Titular de Oftalmologia

Escola Paulista de Medicina - Universidade Federal de São Paulo. ná-la e exercê-la toda, bem. No Brasil, deixou de ser uma escolha de poucos e se expandiu numericamente muito mais do que qualquer outra parte da Medicina. Maior competição, melhores serviços. Daí, também, a diversificação e o altíssimo nível de aptidões no exercício de atividades da Oftalmologia brasileira, dando-lhe o respeito internacional, assegurando a certeza de que o que não pode ser bem resolvido aqui, tampouco alhures terá solução melhor. A cada dia, aparecem novos (e dispendiosos) equipamentos, tornando a constante atualização instrumental uma forma sofisticada de escravização: trabalha-se duro para se poder, amanhã, adquirir uma aparelhagem que possibilite continuar-se na ciranda: a cara novidade de ontem é a obsolescência de hoje e a sucata de amanhã. Mas se a Oftalmologia inviabiliza, economicamente, a montagem pessoal de consultórios completos, enseja a formação de cooperativas para consegui-los. Propõe o trabalho associativo, para que o domínio de conhecimentos de cada componente do grupo assegure a excelência do conjunto. Surgem modelos empresariais de comando e subordinação, ou de associações cooperativas ou, apenas, de comunidades de ofertas de serviços complementares. Acaba o tempo do profissional liberal: surgem as agências prestadoras de serviços conveniados; extingue-se a ação profissional independente, emerge a do trabalho solidário.

Tudo mudou. Na área dos conhecimentos é quase com um sorriso complacente sobre as ironias da ciência que, quem já viveu o tempo da facectomia intracapsular, filosofa: o grande desastre de ontem, a fragmentação do cristalino, converte-se em virtude de hoje. Assusta o privilégio de viver a correção óptica do afácico passando das grossas lentes de óculos às de contacto e, hoje, às intraoculares. Desnorteia comprovar que a imaginação delirante de esculpir uma estrutura tão nobre e quase intocável quanto a córnea se tornasse em poucos anos não apenas exequível mas, ainda mais surpreendente, transformada num ato rápido e corriqueiro. E só quem presenciou as longas internações do pré- e pós-operatório de um descolamento de retina (com seus resultados problemáticos), pode se maravilhar com a ousadia da vitrectomia e com a dimensão de sua feitura ambulatorial.

Tudo mudou e não há dúvidas: a instrumentação diagnóstica e o arsenal terapêutico hoje disponíveis dão a noviços mais condições de resolver problemas do que tinham os mais experientes e veneráveis oftalmologistas do passado, com 
todos seus conhecimentos e habilidades acumuladas. Por outro lado, até mesmo a análise de um procedimento se torna bem mais complexa, pelo menos no que concerne à interpretação da validade de sua aplicação, comprometendo-se seus resultados a descritores variados e muitas vezes conflitantes sobre eficácia (quantidade da mudança), previsibilidade de objetivos, permanência dos efeitos, confiabilidade (conservação ou melhoria da função), custo, relação risco por benefício, etc.

Pois são justamente nas ponderações e diferenciações entre o que sejam indicações indispensáveis ou convenientes, opcionais ou indesejáveis, seguras ou arriscadas, insubstituíveis ou supérfluas, heróicas ou desnecessárias (e por aí afora), são nessas tomadas de decisões sobre oponências que não oferecem para limitá-las a segurança de uma linha divisória, ainda que fosse tênue, é num desses pantanais de dúvidas e perplexidades que muitas vezes nos achamos para responder ao questionamento fundamental de uma consulta: "e então?"

E então é que vem aquele necessário ingrediente da consciência moral e da formação ética, com que se forjam as dife- renças. Não basta a educação científica, pois nas fronteiras do conhecimento o que importa é como aplicá-lo. Mais ainda em Medicina, interface de vida e morte, alegria e dor, esperança e sofrimento, profissão e sacerdócio, luz e trevas, nitidez ou borrão. É nela onde mais aparecem o verdadeiro e o falso, o prudente e o charlatão, o consolador e o aproveitador.

É claro que os caminhos da dignidade ou da abjeção, da santidade ou do pecado, começam a ser ensinados e decididos desde o berço, na família e nas escolas, nos templos e nos grupos de convivência, enfim, em todo lugar e circuntâncias. Por isso mesmo, por nunca terminar a transformação externa e interna de uma pessoa, por lhe serem necessárias (ainda que insuficientes) e para que atuem como elementos na formação de sua integridade (a contrapontuar sua ciência), urge prover reflexões sobre o assunto. Em nossos cursos de Graduação, de Residência e de Pós-Graduação. Em nossas reuniões e Congressos. Em nossos escritos e conversas. Em nossas ações e reações. Em nossa vida. Para que tudo que mude se faça com ciência e consciência.

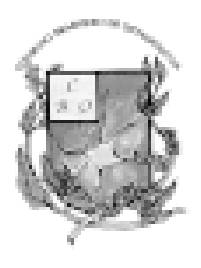

\title{
$14^{\circ}$ Congresso Brasileiro de Prevenção da Cegueira e Reabilitação Visual
}

\author{
6 a 9 de setembro de 2000 \\ Centro de Convenções de Natal - Natal/RN
}

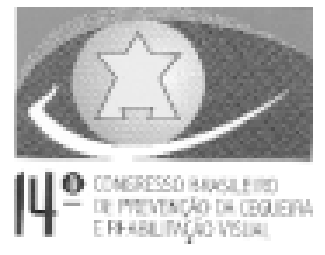

FAÇA JÁ SUA INSCRIÇÃO E GANHE PRÊMIOS!
Os colegas que fizerem sua inscrição até o dia 30 de Julho de 2000, estarão concorrendo ao sorteio dos seguintes prêmios:

- 1 pacote de viagem de 5 dias para Natal, para participar do Congresso - 1 pacote de viagem, pré ou pós-congresso, de 3 dias para Fernando de Noronha

Os sorteios serão feitos pela Diretoria do CBO, nos dias 30/05/2000 e 30/07/2000. Os premiados serão comunicados por telefone e correio e seus nomes serão divulgados nos comunicados do Congresso.

INFORMAÇÕES: CBO Eventos

Al. Santos, 1343 / Conj. 1110 - CEP: 01419-001 - São Paulo - SP - Tel: (0xx11) 3266-4000 / Fax: (0xx11) 3171-0948

E-mail: eventos@cbo.com.br 